\title{
The Effect of Store Attributes Towards Store Format Choice for Beauty Products on Y Generation
}

\author{
Audy Daniaguitrianda Mutiarani ${ }^{1, *}$ Rifelly Dewi Astuti ${ }^{2}$ \\ ${ }^{1}$ Universitas Indonesia \\ ${ }^{2}$ Universitas Indonesia \\ *Corresponding author.Email: audydania@gmail.com
}

\begin{abstract}
There is a growth potential for beauty products in Indonesia. Jakarta as a capital city and the surrounding areas, which have many malls opening with beauty stores inside, comes with various store formats. This study aims to investigate the influence of store attributes toward patronage intention on $\mathrm{Y}$ generation consumers that leads to beauty products store format choice. Store formats investigated in this study were department store and specialty store, where is known that there is a tight competition. Data were taken from 240 respondents who bought beauty product at least once in a month. This study was analyzed using structural equation modeling (SEM), mediation regression, and independent $\mathrm{t}$ test. After processing the data, it was shown that the relation between the atmosphere and merchandising of store attribute's dimension to patronage intention was statistically significant through satisfaction as mediator. Meanwhile, there was a significant direct relation between the price of store attribute's dimension to patronage intention. The result of mediation regression showed that satisfaction mediated partially in the relation between store attributes and patronage intention. Independent $t$-test showed that there was a significant difference in consumer perception toward products at a department store and specialty store.
\end{abstract}

Keywords: UTAUT2, on-Demand Services Application, Perceived Privacy.

\section{INTRODUCTION}

According to Indonesia Ministry of Industry, the national cosmetics industry is growing by $20 \%$. Indonesia cosmetics market is quite large and has potentials. One of the potentials is the population of $\mathrm{Y}$ generation. According to the CEO of Tabs Analytics, Kurt Jetta, millennials is the highest skin care products consumers. Reference [1] reported that in the recent years, there is a shift of beauty product purchase behavior which used to be dominated by department store format but now challenged by beauty product specialty store format. The competition between retailers of beauty products gives an impact on the department store business in Indonesia. There are some department stores are closed. Meanwhile, beauty product specialty stores are widening its business by continuing to open new stores.

Some research have examined store attributes as a very important marketing-mix variable that influences consumers' buying intentions, evaluation of stores, and store choice behavior [2]. Some studies found that positive physical or store environment was likely to have a positive influence on satisfaction, loyalty, and purchase intentions [3]; [4]. Physical store relationships and satisfaction was also examined by [5].

which felt that positive evaluation of the store could result in customer satisfaction. Reference [2] found satisfaction was a mediator in the relationship between store attributes and patronage intention. The customer's satisfaction was affected by the psychical environment of the store, the various procedures they have to follow, the moments of contact with personnel and the core offer of the retailer, such as product variety, assortment, quality and pricing policy [6]. Reference [7] revealed that exploratory factor analysis (EFA) found the dimensions that describe store attributes are products, pricing, atmosphere, personnel, merchandising and in-store convenience.

This study aims to know what factors of store attributes that affect consumers in choosing a beauty product store format by using patronage intention as theory foundation. Store attributes and patronage 
intention have been found to have a relation with customer satisfaction in previous studies. Therefore, the researcher would also like to find out the role of satisfaction between patronage intention and store attributes relationship. The store format examined in this study were department store and specialty store, which have different attributes and at this moment is having a tough competition. This study is expected to help both of product marketers and retailers, to develop or improve marketing strate gies by knowing what store attributes that is wanted and needed by $\mathrm{Y}$ generation consumers in purchasing beauty products. Therefore, their store or products may be chosen by consumers, especially the $\mathrm{Y}$ generation consumers as the largest population.

\section{METHODS}

\subsection{Model}

Referring to [2], the relationship between store attributes and patronage intention and the role of satisfaction in the relationship was examined. The relation was conducted by using store attribute dimensions, which was found by [7]. In-store convenience dimension was not included in the study because the indicators did not relate to beauty product store attributes. Reference [2] found an indirectrelationship between store attribute and patronage intention. Satisfaction found as a mediator that influences store attributes and patronage intention. Therefore, in this study, the role of satisfaction as a mediator in the relation between store attribute and patronage intention was examined. Figure 1 shows the research model.

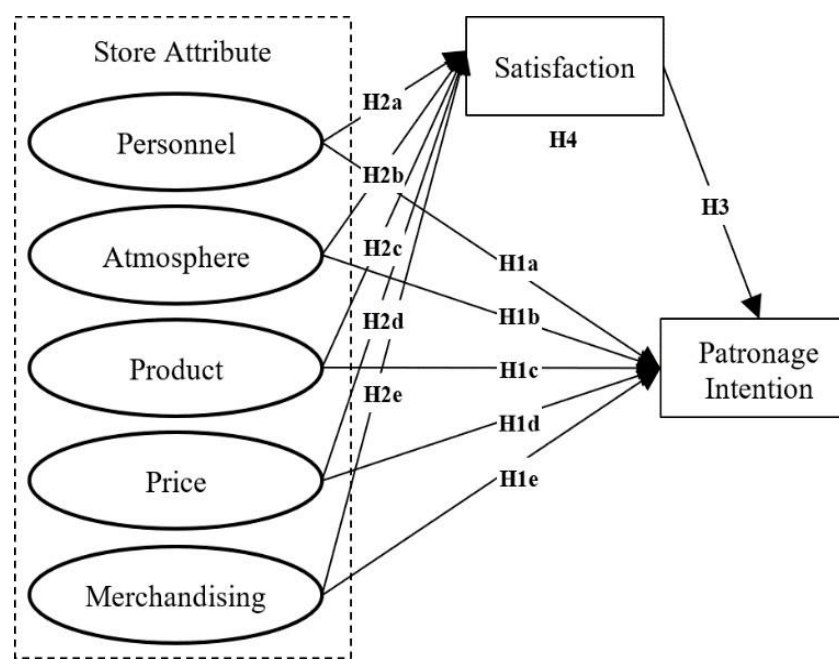

Figure 1 Research Model.

Reference [8] and [9] found store attributes helped in creating shopping experiences that became strong determinants of customer satisfaction and patronage intention. Reference [10] opined that there was a link between store environment,store choice, and patronage intention and attributes could be used to create typology of male grocery shoppers.

H1: (a) personnel, (b) atmosphere, (c) products, (d) price and (e) merchandising in the store increasepatronage intention.

Reference [7] has examined the influence of store attributes toward consumer satisfaction. The results of the study found significant relationships between store attribute dimensions, personnel, product, price, in-store convenience, and satisfaction. Reference [2] also found relation between store attributes and customer satisfaction.

H2: (a) personnel, (b) atmosphere, (c) products, (d) price and (e) merchandising in the store positively affect customer satisfaction.

According to [11] and [12], a critical issue for retail management is to determine the factors affecting satisfaction, to identify and target segments of customers, to ensure patronage on a long-term basis. The opinion is supported by [13] that they suggested customer satisfaction to be the strongest antecedent to patronage intention. Reference [2] found a significant relation between satisfaction and patronage intention.

$\mathrm{H} 3$ : Consumer satisfaction increases patronage intention.

Based on the research conducted by [8], [9], and [4], store attributes affected retailing behavior through creating customer satisfaction that positively impacted customers' behavioral intentions. Consumers seeking cues in the physical environment and satisfaction is closely linked to store choice depending upon whether the chosen storemeets or exceeds expectations [14]; [15].

H4: Satisfaction acts as a mediator between store attributes and patronage intention.

Reference [16] stated that consumer perception of the store attributes affected their preference for stores based on their postvisit ranking of the stores. According to [17], patronage behavior can be different for different types of retailers. Department store and specialty store have a different store attribute. Therefore, it may affect the consumer perception.

H5: There is a difference in consumers' perceptions of (a) personnel, (b) atmosphere, (c) products, (d) price and (e) merchandising in the department stores and specialty stores.

\subsection{Method}

Samples for this study were beauty product consumers aged 18-38 years, domiciled in Jakarta and the surrounding areas who at least bought beauty products once in a month. The data were processed using SPSS software version 25 and LISREL version 8.8. This study was analyzed using structural equation modeling (SEM), 
mediation regression and independent t- test. In the final questionnaire, store attributes (adapted from [7]) were measured with five dimensions, personnel (five item statements), ambiance (four item statements), product (three item statements), price (three item statements) and merchandising (three item statements). Patronage intention (adapted from [18]) was measured with three item statements. Satisfaction (adapted from [7]) was measured with three item statements. 5-point Likert rating scale were used.

\section{RESULTS AND DISCUSSION}

Prior to the further data processing, the data of the 240 respondents were tested for validity and reliability. Based on the test results, all variable item statements were considered valid and reliable.

\subsection{Structural Equation Modeling (SEM) Analysis}

In this study, confirmatory factor analysis (CFA) was conducted. From the test result, it was concluded that all variables were valid and reliable to be used. This study also tested the model by measuring the suitability of Goodness of Fit (GOF). The results of the test show the research model is fit $(\mathrm{GFI}=0.9, \mathrm{RMSEA}=0.049, \mathrm{RMR}$ $=0031$, NFI $=0.97$, IFI $=0.99$, and CFI $=0.99$ ). Therefore, it was concluded that the research model could be used to test the research hypothesis. Table 1 shows the SEM analysis results.

From Table 1, it is known that the price has a significant relation to patronage intention, with the value of 2.28 . It means if a store offers good price, it may directly increase consumer patronage intention. In other words, the store format which offers a better price, can be directly selected or visited by consumers. However, this study did not find a significant relation between other store attribute dimensions, namely, personnel, atmosphere, product and merchandising, and patronage intention. The results are supported by [2], where the relation between with store attribute and patronage intention was not found significant. Store attribute did not affect the consumer to visit or shop at the store directly, but through the mediation of satisfaction. Reference [19] found promotions, convenience, and merchandising in the store had no direct relationship to patronage intention, yet through store image. It can be concluded that $\mathrm{H} 1$ was partially accepted, which only the price would increase patronage intention directly.
Table 1. SEM Analysis Results

\begin{tabular}{|l|l|l|}
\hline Path & T-Value & Conclusion \\
\hline Personnel $\rightarrow$ Patronage & $-1,61$ & Nonsignificant \\
\hline Atmosphere $\rightarrow$ Patronage & 1,20 & Nonsignificant \\
\hline Product $\rightarrow$ Patronage & $-0,52$ & Nonsignificant \\
\hline Price $\rightarrow$ Patronage & 2,28 & Significant \\
\hline $\begin{array}{l}\text { Merchandising } \rightarrow \\
\text { Patronage }\end{array}$ & 0,25 & Nonsignificant \\
\hline Personnel $\rightarrow$ Satisfaction & 0,52 & Nonsignificant \\
\hline $\begin{array}{l}\text { Atmosphere } \rightarrow \\
\text { Satisfaction }\end{array}$ & 2,53 & Significant \\
\hline Product $\rightarrow$ Satisfaction & $-1,09$ & Nonsignificant \\
\hline Price $\rightarrow$ Satisfaction & 1,77 & Nonsignificant \\
\hline $\begin{array}{l}\text { Merchandising } \rightarrow \\
\text { Satisfaction }\end{array}$ & 2,65 & Significant \\
\hline Satisfaction $\rightarrow$ Patronage & 6,12 & Significant \\
\hline
\end{tabular}

Table 2. Variable

\begin{tabular}{|c|c|c|c|}
\hline Variable & $\mathbf{X} \rightarrow \mathbf{Y}$ & $\mathbf{X}^{\prime} \rightarrow \mathbf{Y}^{\prime}$ & Indirect \\
\hline \multirow[t]{2}{*}{ Personnel } & Coef $-0,025$ & $-0,096$ & \multirow[t]{2}{*}{0,071} \\
\hline & \begin{tabular}{|l|l|} 
Sig. & 0,763 \\
\end{tabular} & 0,190 & \\
\hline \multirow[t]{2}{*}{ Atmosphere } & Coef. 0,263 & 0,117 & \multirow[t]{2}{*}{0,146} \\
\hline & Sig. 0,000 & 0,085 & \\
\hline \multirow[t]{2}{*}{ Product } & Coef.- $-0,010$ & $-0,018$ & \multirow[t]{2}{*}{0,007} \\
\hline & \begin{tabular}{|l|l|} 
Sig. & 0,907 \\
\end{tabular} & 0,820 & \\
\hline \multirow[t]{2}{*}{ Price } & Coef.0,235 & 0,145 & \multirow[t]{2}{*}{0,090} \\
\hline & \begin{tabular}{|l|l|} 
Sig. & 0,004 \\
\end{tabular} & 0,046 & \\
\hline \multirow[t]{2}{*}{ Merchandising } & Coef. 0,202 & 0,061 & \multirow[t]{2}{*}{0,141} \\
\hline & \begin{tabular}{|l|l} 
Sig. & 0,010
\end{tabular} & 0,390 & \\
\hline
\end{tabular}

It can be seen in the data that the atmosphere and merchandising have a significant relation to satisfaction, with the value of 2.53 and 2.65. Results from this study aligns with [2], which found a significant relation between the store attributes and satisfaction. Reference [7] found the personnel, product, price and in-store convenience had a significant relation to satisfaction. However, this study only found a significant relation between atmosphere, merchandising and satisfaction. The difference may occur due to different industries. This study examined the beauty industry where shopping activities not only to fulfil the needs, but part of the entertainment as well. Therefore, a comfortable atmosphere and a good merchandising may satisfy the consumer. Reference [20] asserted that marketing researchers have come to realize that the physical store environment experienced at the point of purchase influenced consumers' shopping behaviorand, therefore, the practice of creating influential atmospheres should be an important marketing strategy for most exchange 
environments. It can be concludedthat $\mathrm{H} 2$ was partially accepted, which only the atmosphere and merchandising positively influenced customer satisfaction.

The results of the test show that satisfaction has a significant relation to patronage intention, with the value of 6.12. The result is supported by [2], where asignificant relation between satisfaction and patronage intention was found. It means when choosing a retail store, consumers will compare the satisfaction or positive thoughts of a store. Consumers will have greater intention to choose a store that has the highestsatisfaction level or higher than other similarshops which sell the same products. It can be concluded that $\mathrm{H} 3$ was accepted, meaning the customer satisfaction increased patronage intention.

\subsection{Mediation with Regression Analysis}

The mediation test conducted in this study used the steps of [21]. The regression of $\mathrm{X}$ to $\mathrm{M}$ had a significant relation with coefficient value of 0.668 (sig. 0.000). M to $\mathrm{Y}$ had a significant relation with coefficient value of 0.562 (sig. 0.000) and $\mathrm{X}^{\prime}$ to $\mathrm{Y}^{\prime}$ had a significant relation withcoefficient value of 0.146 (sig. 0.025). The indirect effect, which was determined through satisfaction, was obtained by multiplying the value of store attributes to satisfaction and satisfaction to patronage intention, 0.668 x $0.562=0.375$. The effect of store attribute dimensions to patronage intention, with and without satisfaction as mediator was also tested. Table 2 shows the mediation analysis results.

\subsection{Mediation Analysis}

The dimensions which are found have a significant influence to satisfaction are atmosphere, price, and merchandising. The influence of satisfaction to patronage intention are also found significant. It is known that the price's indirect effect value (0.090) is lower than the direct effect value $(0.145)$. It means that the price relation to patronage intention is not mediated by satisfaction. From the test results, it can be concluded that the dimension which has a significant relation to the patronage intention are atmosphere, price and merchandising, as the atmosphere and merchandising is mediated by satisfaction. The value of adirect relation

Table 3 Independent T-Test Analysis

\begin{tabular}{|c|c|c|c|c|c|}
\hline \multirow[t]{2}{*}{ Variable } & \multirow[t]{2}{*}{$\begin{array}{l}\text { Form } \\
\text { at }\end{array}$} & \multirow[t]{2}{*}{$\begin{array}{l}\text { Mea } \\
\text { n }\end{array}$} & \multicolumn{2}{|c|}{$\begin{array}{l}\text { Levene's } \\
\text { Test }\end{array}$} & \multirow{2}{*}{$\begin{array}{l}\mathbf{P} \\
\text { Val } \\
\text { ue }\end{array}$} \\
\hline & & & $\mathrm{F}$ & Sig. & \\
\hline \multirow[t]{3}{*}{ Personnel } & Dept. & 20,4 & \multirow{3}{*}{$\begin{array}{l}0,48 \\
8\end{array}$} & \multirow{3}{*}{$\begin{array}{l}0,48 \\
8\end{array}$} & \multirow{3}{*}{$\begin{array}{l}0,61 \\
2\end{array}$} \\
\hline & Store & 3 & & & \\
\hline & $\begin{array}{l}\text { Spec. } \\
\text { Store }\end{array}$ & $\begin{array}{l}20,6 \\
4\end{array}$ & & & \\
\hline $\begin{array}{l}\text { Atmospher } \\
\mathrm{e}\end{array}$ & $\begin{array}{l}\text { Dept. } \\
\text { Store }\end{array}$ & $\begin{array}{l}16,9 \\
3\end{array}$ & $\begin{array}{l}0,81 \\
3\end{array}$ & $\begin{array}{l}0,81 \\
3\end{array}$ & $\begin{array}{l}0,40 \\
8\end{array}$ \\
\hline
\end{tabular}

with satisfaction between store attribute and patronage intention was 0.146 and the value of an indirect relation with satisfaction was 0.375 . The indirect relation through satisfaction is greater than direct relation. It means satisfaction is a mediatorin the relation between store attributes and patronageintention. The result supports the study that has beenconducted by [2], where it was also found that satisfaction acted as a mediator in the relationship between store attributes and patronage intention. Therefore, it can be concluded that $\mathrm{H} 4$ was accepted, satisfaction acted as a mediator between store attributes and patronage intention. However, the test also shows that the entire relation has a significance value < 0.05 , which indicates a partial mediation. The partial mediation happens because satisfaction was not found to mediate the relation of price to patronage intention.

\subsection{Independent T-Test Analysis}

From the test results of independent t-test, it can be found only the product that has p-value $<0.05(0,009)$ (see Table 3). Therefore, it can be concluded that H5 is partially accepted, which only the product in department stores and specialty stores that has a different perception of consumers. According to Yongky S. Susilo, whois an expert staff of the Indonesian Retailers Association, Indonesia's retail industry has become even more crowded, dynamic, and increasingly demand higher innovation. Stores are required to change in order to create a new segment. It may have an impact on the store attributes which based on this study resultwas not found to have a much different perception between store formats. For the products in the store, there wasstill found differences. It means the variety, quality, and availability of the products offered at a department store and specialty store were considered different by consumers. The addition of a new product variation is needed to be done by the department store. Product variation is a business challenge that exists because of the advent of specialty stores. The beauty product specialty stores come with products and brands that more varied than the department store, which align with the results of this study that the average value of consumer perception towards products on specialty store was higher than departmentstore.

\begin{tabular}{|c|c|c|c|c|c|}
\hline & $\begin{array}{l}\text { Spec. } \\
\text { Store }\end{array}$ & $\begin{array}{l}16,6 \\
8\end{array}$ & & & \\
\hline \multirow[t]{3}{*}{ Product } & Dept. & 12,1 & \multirow{3}{*}{$\begin{array}{l}0,81 \\
4\end{array}$} & \multirow{3}{*}{$\begin{array}{l}0,81 \\
4\end{array}$} & \multirow{3}{*}{$\begin{array}{l}0,00 \\
9\end{array}$} \\
\hline & Store & 7 & & & \\
\hline & $\begin{array}{l}\text { Spec. } \\
\text { Store }\end{array}$ & $\begin{array}{l}12,8 \\
6\end{array}$ & & & \\
\hline \multirow[t]{3}{*}{ Price } & Dept. & 11,6 & \multirow{3}{*}{$\begin{array}{l}0,69 \\
9\end{array}$} & \multirow{3}{*}{$\begin{array}{l}0,69 \\
9\end{array}$} & \multirow{3}{*}{$\begin{array}{l}0,71 \\
8\end{array}$} \\
\hline & Store & 4 & & & \\
\hline & $\begin{array}{l}\text { Spec. } \\
\text { Store }\end{array}$ & $\begin{array}{l}11,7 \\
5\end{array}$ & & & \\
\hline
\end{tabular}




\begin{tabular}{|l|l|l|l|l|l|}
\hline \multirow{2}{*}{ Merchandis } & Dept. & 12,2 & 0,58 & 0,58 & 0,05 \\
& Store & 1 & 7 & 7 & 6 \\
\cline { 2 - 5 } & Spec. & 12,6 & & & \\
& Store & 8 & & & \\
\hline
\end{tabular}

\section{CONCLUSIONS}

The results of the analysis showed that price might increase patronage intention. It means the store which offers a good price for $\mathrm{Y}$ generation consumers will influence consumers' intention to visit or to shopin the store. From the results of the mediation regression analysis, it was known that satisfaction was a mediator in the relation of store attributes and patronage intention. In other words, store attributes that give positive thought or satisfaction to the $\mathrm{Y}$ generation consumers may influence consumer patronage intention. Although the mediating role of satisfaction in therelation of store attributes and patronage intention was partial mediation. The SEM test results showed that theatmosphere and merchandising in the store positively influenced customer satisfaction. From the results, it can be concluded that the price, atmosphere, and merchandising had an influence on patronage intention on $\mathrm{Y}$ generation consumers for beauty products. The differences in consumer perception of store attributes between department stores and specialty stores were found only for the product. It means stores are evolved in order to compete and survive in a tight retail competition. The results of the evolution lead to the consumer perception between store format were not significantly different. However, it was still found a significant difference for the product due to specialty stores coming with products and brands that are more varied than the department store.

\section{Managerial Implications}

This study found a significant relation betweenstore attribute and patronage intention on $\mathrm{Y}$ generation consumers. Therefore, when marketers or retailers of beauty products would like to increase the frequency of visits, it is necessary to evaluate the attributes of their existing stores. Store attributes thatwere found to have a significant relation were the atmosphere, merchandising, and price. Therefore, the marketers or retailers may start to improve the quality of those attributes first. The relation between atmosphere and merchandising was mediated by satisfaction. By having comfortable atmosphere, interesting product arrangement and clear product information, the Y generation consumers may have a positive thought ofthe store which leads to that consumers store choice. The price was directly related to patronage intention, so when marketers or retailers of beauty products need a direct response to consumers visit and shop at their store, they may offer promotion or sale price. Specialty stores are considered by the $\mathrm{Y}$ generation consumers to have a better product variation. Therefore, the department store retailer is suggested to enhance or improve the variety of products and brands offered at the store in order to be able to compete with specialty stores.

\section{REFERENCES}

[1] Tabs Analytics, "Millennials, hispanics and online are fueling the growth in the $\$ 25$ billion cosmetics and skincare categories.," Tabs Analytics, 2016.

[2] S. R. Nair, "Analyzing the relationship between store attributes, satisfaction, patronage-intention and lifestyle in food and grocery store choice behavior,” Int. J. Retail Distrib. Manag., 2018.

[3] G. Das, "Impact of store image on store loyalty and purchase intention: Does it vary across gender?," Int. J. Electron. Mark. Retail., 2014.

[4] F. Ali and M. Amin, "The influence of physical environment on emotions, customer satisfaction and behavioural intentions in Chinese resort hotel industry," J. Glob. Bus. Adv., 2014.

[5] M. Söderlund, H. Berg, and J. Ringbo, "When the customer has left the store: An examination of the potential for satisfaction rub-off effects and purchase versus no purchase implications," J. Retail. Consum. Serv., 2014.

[6] D. Morschett, B. Swoboda, and T. Foscht, "Perception of store attributes and overall attitude towards grocery retailers: The role of shopping motives," Int. Rev. Retail. Distrib. Consum. Res., 2005.

[7] P. K. Theodoridis and K. C. Chatzipanagiotou, "Store image attributes and customer satisfaction across different customer profiles within the supermarket sector in Greece,” Eur. J. Mark., 2009.

[8] D. Sharma, "Examining the influence of service quality on customer satisfaction and patronage intentions in convenience store industry," Int. J. Bus. Glob., 2015.

[9] I. O. Pappas, A. G. Pateli, M. N. Giannakos, and V. Chrissikopoulos, "Moderating effects of online shopping experience on customer satisfaction and repurchase intentions," Int. J. Retail Distrib. Manag., 2014.

[10]L. L. Berry, A. Parasuraman, and V. A. Zeithaml, "SERVQUAL: A multiple-item scale for measuring consumer perceptions of service quality," J. Retail., 1988.

[11]M. J. Bitner, "Evaluating service encounters: The effects of physical surroundings and employee responses," J. Mark., 1990.

[12]E. Sivadas and J. L. Baker-Prewitt, "An examination of the relationship between service 
quality, customer satisfaction, and store loyalty," International Journal of Retail \& Distribution Management. 2000.

[13]D. Grace and A. O'Cass, "An examination of the antecedents of repatronage intentions across different retail store formats," J. Retail. Consum. Serv., 2005.

[14] J. Bloemer and K. de Ruyter, "On the relationship between store image, store satisfaction and store loyalty," Eur. J. Mark., 1998.

[15] J. J. Cronin, M. K. Brady, and G. T. M. Hult, "Assessing the effects of quality, value, and customer satisfaction on consumer behavioral intentions in service environments," J. Retail., 2000.

[16]D. C. Lin Thang and B. L. B. Tan, "Linking consumer perception to preference of retail stores: An empirical assessment of the multi-attributes of store image," J. Retail. Consum. Serv., 2003.

[17] B. R. Berman and J. R. Evans, Retail Management: A Strategic Approach (13th Edition). 2010.

[18] D. Grewal, J. Baker, M. Levy, and G. B. Voss, "The effects of wait expectations and store atmosphere evaluations on patronage intentions in serviceintensive retail stores," J. Retail., 2003.

[19]B. G. Muchardie, F. Yosa, and A. Gunawan, "Comparative study of store image, patronage intention, and retail mix elements between Alfamart and Indomaret in Jakarta," Binus Bus. Rev., 2017.

[20] L. W. Turley and R. E. Milliman, "Atmospheric effects on shopping behavior: A review of the experimental evidence," J. Bus. Res., 2000.

[21]Reuben M. Baron and David A. Kenny, "The moderator-mediator variable distinction in social psychological research: Conceptual, Strategic, and statistical considerations," J. Pers. Soc. Psychol., vol. 51, no. 6, pp. 1173-1182, 1986. 